\title{
НОВИ ИЗСЛЕДВАНИЯ В ОБЛАСТТА НА СРАВНИТЕЛНАТА СЛАВЯНСКА МОРФОЛОГИЯ
}

\author{
Margarita RumenOVA \\ Uniwersytet Masaryka w Brnie
}

\begin{abstract}
NEW RESEARCH IN THE FIELD OF COMPARATIVE SLAVIC MORPHOLOGY. A review of: Stoychev, Stiliyan. The Bulgarian Resultative Form and the Czech Language. On the Modern Bulgarian Morphological Resultative Form and its Functional Equivalents in the Modern Czech Language. Sofia: Silhouette, 2019, 356 pp. ISBN 978-619-194-053-0; Stoychev, Stiliyan. The Bulgarian Relative Form and the Czech Language. On the Modern Bulgarian Morphological Relative Form and its Functional Equivalents in the Modern Czech Language. Sofia: Silhouette, 2019, 405 pp. ISBN 978-619-194-054-7.
\end{abstract}

Keywords: Stiliyan Stoychev, resultative form, relative form, Bulgarian language, Czech language

През последните десетилетия сравнителното славянско езикознание обръща голямо внимание на функционалните еквиваленти на различни морфологични категории между отделните славянски езици, което представлява много ценен принос както в чисто теоретичен аспект, така и в областта на преводознанието и на самата преводаческа практика, а също и в областта на дидактиката - на преподаването на славянските езици като чужди. В този контекст през 2019 година сравнителните изследвания в областта на славянската морфология бяха обогатени с издаването на два труда на дългогодишния преподавател по чешки език в Софийския университет д-р Стилиян Стойчев: Българският морфологичен резултатив и чешкият език или за съвременния български морфологичен резултатив и неговите функционални еквиваленти в съвременния чешки език и Българският морфологичен релатив и чешкият език или за съвременния български морфологичен релатив и неговите функционални еквиваленти в съвременния чешки език. 
Монографията Българският морфологичен резултатив и чешкият език или за съвременния български морфологичен резултатив и неговите функционални еквиваленти в съвременния чешки език за първи път както в българското, така и в чешкото езикознание прилага метода за установяване на чуждоезична функционална еквивалентност при изследване на резултативността в българския и чешкия език. Авторът представя синхронен анализ на морфологичния резултатив в съвременния български език както в синтагматичен, така и в парадигматичен план, дефиниран като маркирана грамема резултатив на двуграмемната българска глаголна морфологична категория вид на действието. Ст. Стойчев също установява и анализира синхронно и класифицира чешките доминантни, основни допълнителни и периферни допълнителни еквиваленти на българския морфологичен резултатив, като изгражда съответните т.нар. функционално еквивалентни ветрила. В този свой труд авторът представя първи опит в българистиката за установяване на т. нар. вътрешноезикова функционална еквивалентност и за моделиране на функционално-семантичното микрополе на резултативността в съвременния български език. Интересни са и наблюденията за по-слабо развитото чисто синтактично микроядро на функционалносемантичното миркополе на резултативността в съвременния чешки език, което дава възможност на Ст. Стойчев да направи може би първото в контрастивната славистика изобщо системно типологично ориентирано синхронно сравнително изследване на резултативността в двата съпоставяни езика.

Монографията Българският морфологичен релатив и чешкият език или за съвременния български морфологичен релатив и неговите функционални еквиваленти в съвременния чешки език е посветена на проявите на конкуренция между различните езикови средства при изразяването на семата релативност в българския и чешкия език, както и на граматичната асиметрия между тях в това отношение. Авторът изследва българските финитни релативни словоформи, т.е. словоформите на маркираната грамема релатив на българската морфологична вербална категория таксис в качеството ѝ на морфологично средство за изразяване на семата релативност, като търси и техните функционални еквиваленти в съвременния български и в съвременния чешки език. Авторът проследява паралелно и конфронтативно проявите на глаголна релативност в двата изследвани езика и в трите темпорални плана - в плана на настоящето, в плана на бъдещето и в плана на миналото. При анализа на различните словоформи на българския морфологичен релатив Ст. Стойчев защитава убеждението, че установяването на евентуални техни вътрешноезикови (т.е. български) функционални еквиваленти предлага и добри идеи за търсене на структурно разнообразни еквиваленти и същевременно теоретично издържани решения при 
превод на тези словоформи на езици, които или никога не са притежавали морфологична категория таксис, или са я изтласкали в периферията на морфологичната си система и са на път да я загубят (какъвто по мнение на автора е чешкият език), или вече са я изгубили.

Анализираният езиков материал и в двете публикации в по-голямата си част е ексцерпиран от паралелните български и чешки текстове, включени в Паралелния корпус на Чешкия национален корпус (в корпуса са включени оригинални български текстове и техни чешки преводи).

Характерно и за двете монографии е задълбоченото познаване от страна на автора на научната литература по изследваните теми (библиографията на всяка от тях включва заглавия не само на чешки и български изследователи, но и трудове на почти всички славянски езици). Авторът представя морфологичните категории резултатив и релатив с прецизност и последователност, с подходящо избрана методология. Изчерпателната теоретична база и многобройните анализирани примери, служещи за илюстрация, могат да бъдат използвани както в процеса на обучение по български език като чужд за представители от други славянски страни, така и при подготовката на бъдещи преводачи.

Направените изводи и установените функционално еквивалентни зависимости, макар и засягащи само два частни случая от българската граматика, биха могли да бъдат интересни и за изследователите както на теорията, така и на практиката при преподаването на български език като чужд, а също така да послужат като импулс за лингвистични изследвания и сравнения и с други славянски езици. 